\title{
A Corpus-based Lexical Study of Contemporary Feminist Short-Story Writers: with Special Reference to Alice Munro
}

A research in Linguistics

By

\author{
Esraa Aly Hasab El-Nabi \\ Under the Supervision of \\ Professor. Ali Gamal El-Deen Ezzat \\ Professor of Linguistics \\ Faculty of Education \\ Ain Shams University \\ And
}

Dr. Azza Abdeen

Lecturer of Linguistics

Faculty of Women for Arts Science and Education

Ain Shams University 


\section{ملخص}

يعتبر هذا البحث دراسة نحوية مبنية علي علم الدونات لخصائص القصة القصيرة لللأدب النسوي مع الاشارة للكاتبة النسوية أليس مانرو. تهدف الدر اسة إلي الكثثف عن السمات اللغوية و تحديد المو اضيع المتكررة التي غالبا ما تتناولها الكاتبة والتي تتعلق بـالظروف المتدهورة للمر أة خـلال القرن العثرين. يتم التحليل عن طريق القاء الضـوء علي الالفاظ الأكثر شيو عا بالإضـافة إلي البحث عن معانيها اللفظية و الدلالية و ملامحها المعجمية المختلفة و مدي دقتها في التعبير عن اتجاهات الكاتبة. بالإضافة الي ذلك، يلقي البحث الضوء علي أهمية إختيار الألفاظ في في تصوير الهوية الأنثوية التي تبناها ألبس مونرو و التي تسود في معظم كتاباتها.ويعتمد البحث في الجانب التطبيقي على نظرية تحليل الألفاظ التي تبناها فيرث. 


\begin{abstract}
This research is a corpus-based study of the lexical features in the short stories of the contemporary female Canadian feminist writer Alice Munro. The aim of the study is to specify recurrent themes related to the deteriorated conditions of women throughout the twentieth century through her lexical choices. The lexical analysis isanalyzedin terms of collocations, concordances, and lexical sets that are frequently used to convey such themes. In addition, the denotations and connotations of the most and the least frequent lexical items with various lexical features are analyzed. Throughout the analysis, special attention is devoted to how these lexical choices help portraying the feminine identity adopted by Alice Munro and prevailing in most of her writings. This is processed using AntConc 3.4.4 software.
\end{abstract}

Key words: Lexical Features, Lexical Sets, Keyness Values, Denotation, Connotation, Corpus Analysis, Feminism.

\title{
1. Introduction:
}

Short story is a brief kind of narration that is shorter than a novel and that usually deals with only a few characters. A short story is usually concerned with a single effect conveyed in only one or a few significant episodes or scenes. This requires economy of setting, concise narrative, and omission of a complex plot. A few characters are disclosed in action and dramatic encounter but are seldom fully developed. Despite its relatively limited scope, a short story is often judged by its ability to provide a "complete" or satisfying treatment of its characters and subject. This requires an accurate writer to be able to send all his/her messages through this short form in which every lexical choice counts.

Hence, testing the feminist views through short form and economy of language is quite problematic, as it demands analyzing the writer's different choices such as the lexical items and categories and to what extent they are efficient in revealing her views.

\section{Purpose of the study:}


The core idea of this research is to explore the fact that studying the language and style of literary works can easily support the reader's understanding and comprehension of the writer's artistic achievements. Writers, specially unique and distinguished ones like Alice Munro, use special linguistic and stylistic tools to achieve certain impression and to lead the reader to specific ideas and messages. Thus, working on the analysis of these items and analyzing literature from linguistic perspective could help readers appreciate the work more comprehensively. To achieve this, this research offers testing stylistic and linguistic features of Alice Munro's production.

\section{Objectives:}

The objectives of this research are:

1- To uncover the strategies adopted by the feminist writer Alice Munro concerning her lexical choices.

2- To show the importance of economy in style that a short story writer must stick to, to reveal his/her views as the short form requires economy of setting, concise narrative, and the omission of a complex plot that is why every word counts.

3- To investigate the characteristics and features ofMunro's lexical choices that are considered distinctive features of feminists.

\section{Research Hypothesis:}

This research hypothesizes that lexical analysis of the collocations and the most and the least frequent lexical items of Alice Munro's short stories together with testing their connotations and denotations would reveal her recurrent themes and stylistic features.

\section{Research Questions:}

This research is an attempt to find answers to the following questions:

1- What are the common and distinctive lexical features that appear in Munro's lexical choices and can be generalized to all feminist short story writers?

2- What are the dominating connotations and denotations of the lexical items that Munro adopts and can be considered common to other feminists?

\section{Significance of the Study}


The study attempts a detailed and comprehensive analysis of the collected data in terms of form and function. Data is examined quantitatively by using AntConc 3.4.4 software to determine the most and the least frequent lexical items, and then qualitatively by drawing significant interpretations of the frequency of these items. The main framework in this study is the Lexical Theory according to theNew Firthian school of Linguistics.

\section{Review of Literature:}

\subsection{Review of Previous Studies:}

Stylistic research on linguistic analysis of literary works has focused on certain linguistic characteristics, either grammatical, lexical, syntactic, semantic, or morphological, in a popular work for a definite writer, and focused on this work only. The main focus of such research was to apply the linguistic theory manually to a definite work adopting qualitative analysis. The results, in most cases, are limited and focused on very narrow scopes within the literary field. Most recent research has tried to follow the analysis of large corpora encompassing to reach more valid results applied on collection of texts.

Stubbs (2001),for instance, focuses his research on the corpus based lexical analysis. He presents words and phrases, how they are used, their meanings, connotations, and denotations. Throughout his research, he provides answers to the questions concerned with how the meanings of words depend on their different uses. Moreover, Biber (2011), in his research, introduces the idea of corpus-based analytical techniques in which corpus-based analysis is introduced and applied to the study of literature. He mentions many scholars and their works within the field of literature using Corpus Linguistics (CL) tools and to what extend using these tools is beneficial to the field of literature and stylistics. For example, he gives full account to the work of Culpeper (2009) and his analysis of the distinctive keywords used by each individual character in Romeo and Juliet. Similarly, he praises the work of Fischer-Stracke, (2009) as he employs the same technique and describes the distinctive keywords of Jane Austin's Northanger Abbey.

According to Flowerdew 2012, pioneers in the field of corpus linguistics, such as Sinclair (1991), Stubbs (1996), and Hunston (2002), all view a corpus as a collection of written or spoken authentic language, which has been compiled and collected for a particular linguistic purpose. They are collected as a "machinereadable form" which can be electronically accessed to be analyzed.(p.3)

\subsubsection{Contribution of the present research:}


It appears vividly that on the level of linguistic analysis of literary works, many writers have tried to analyze linguistic characteristics of literary works using corpus-based approach, and this trend is very recommended by pioneer linguists. On the other hand, this never happened with the works of Alice Munro, being feminists' representative. On the level of literary analysis, Alice Munro's works have gone under research several times but from a literary perspective. Researchhas analyzed her style of writing from a literary point of view tackling her prevailing themes, her distinguished images and her continuous support of women. Thus, this research is intended to test her distinctive linguistic features using corpus-based approach to reach and clarify common linguistic features characterizing her style of writing, and consequently reaching common linguistic features of feminists in general.

\subsection{Lexical Level of Analysis:}

The lexical analysis throughout the research aims to examine the accuracy of lexical choices of a pioneer short story writer in an aim of tracking the most prominent distinctive features of feminist short story writers in general according to the New Firthian School of linguistics. To this end, first the core of lexical items, collocations, and lexical sets are clarified. Then, different types of meanings are discussed with special reference to the denotative and connotative meanings of various lexical items chosen according to their number of hits that clearly appears using the computer software.

The research focuses on lexical analysis as a separate level of analysis focusing on lexical items in different linguistic contexts. According to Ezzat (1973), analyzing lexical items from a lexical point of view with their different meanings, apart from their "grammatical considerations" is extremely useful for better understanding of a given text as well as uncovering the intentions and the point of view of the writer (p.25). A lexical item according to him is defined as an item "which enters into a certain kind of choice different from a grammatical choice"(p.25). Lexicology or lexical analysis is mainly concerned with the collocations or the words that habitually keep company.

InIn Memory of J.R Firth (1966), Halliday provides in his essay "Lexis as a Linguistic Level" the fact that the level of lexical analysis is totally related to the lexical restriction. Lexical restriction, according to Halliday, is the extent to which an item is specified by its collocational environment. He then states his idea and comments on this saying that this consequently takes into account the frequency of the item under investigation in a stated environment, compared to the total frequency of occurrence (pp. 148-162). 


\subsubsection{Sets and Collocations:}

While describing the lexis of any piece of writing, there are two fundamental categories which are Sets and Collocations. According to Ezzat (1973), "lexical set is defined as a group of lexical items which have similar collocational ranges. Any given lexical item habitually occurs or collocates with a range of other lexical items"(p. 61). Then he adds that within the analysis, "the item under discussion is termed the node or nodal item, whereas the items with which it is usually associated are termed the collocates."(pp.61-62)

Afterwards, he refers to the idea of collocations saying:

Collocation accounts for the fact that many items in a given language have high probability of co-occurrence with other items in the same language. This co-occurrence must be in terms of the regular tendency of a particular item to keep the company of other lexical items.(p.62)

These items, as Firth mentions, are 'mutually expectant', i.e., this means that an item expects the other. He defines collocational relations asthe criterion to which items are distributed into sets. Thus, items that show certain degree of 'likeness', as he referred to it, in their collocational patterning are always assigned to the same sets. He refers to the items being examined as'the node', and refers to what comes after or before to 'the collocates' up to two items following or preceding. Then, the occurrence of collocates will show certain frequency of distribution within a given corpus.

\subsubsection{Denotative and connotative meanings}

According to A Glossary of American Technical Linguistic Usage, the expression connotation means "supplementary values of meaning relating often to certain external circumstances in which the form has been heard"(1966, p.24). According to The Concise Oxford Dictionary of Linguistics, connotation is an expression "used variously to refer to differences in meaning that cannot be reduced to difference in denotation"(2005, p.69). According to the Cambridge Encyclopedia of Language, denotative meaning is "the objective (dictionary) relationship between a word and the reality to which it refers"(1997, p.425); thus denotation is a relation between a term in the language and a range of referents in the world.

\subsection{Corpus Linguistics:}


CL studies the human language through using large corpora computationally, and tries to understand how human beings have the capacity to produce language. That is why CL is considered a part of the broader branch "Computational Linguistics", and tends to study large amount of language in use through computational tools. CL is an analytical method of linguistic analysis and description which focuses and depends on corpora as its primary data. Corpus analysis' main target is to study word lists, concordances, collocations and keywords. This is, through statistical form, leads to valid and clear results to be analyzed contextually according to the researcher hypothesis. This kind of analysis is primarily quantitative and qualitative, interested in the context of situation specially the analysis of concordance. Kennedy (1998) refers to the field of CL as a whole as "A scholarly enterprise concerned with the compilation and analysis of corpora" (p.1). He also focuses on the fact that Corpus based research depends on both qualitative and quantitative methods of analysis

\subsubsection{Corpus Stylistics:}

Actually, over the last 50 years, corpus-based research methods have been extensively used for the aim of studying literature. Within the past decade, this research has become popular, carried under the umbrella of the so-called 'corpus stylistics'. These kinds of research have a clear target of blending both methods of corpus analysis and its qualitative and quantitative results as well as the traditional stylistic aims of stylistic research. However, this new technique, according to Biber (2011), " seems to be of great potential for new lines of research that integrate the statistical methods of earlier research with the more rhetorical concerns of recent studies" (p.21). Thus, applying corpus linguistics tools to literary texts is commonly referred to as "Corpus Stylistics" and signifies an engagement between corpus linguistics and literary stylistics.

\section{Alice Munro, A Noble Prize Winner:}

Alice Munro is the first Canadian Noble Prize recipient in Literature after Saul Bellow who was awarded the Noble Prize in 1976. According to The New York Times, in October 2013, at the age of 82, she won the Noble Prize in Literature and was referred to later as the "master of the contemporary short story". She is considered the first Canadian woman to receive the Noble Prize in Literature and the first woman to win a literature prize since Mueller in 2009. Besides, she can be considered the $13^{\text {th }}$ female to win a literature prize since it was founded in 1901. 
Then, on receiving the prize, she comments saying: "I would hope that this would make people see the short story as an important art, not just something that you played around with until you'd get a novel written".(Bosman, 2013)

\section{Methodology:}

This research is a corpus based study combining both qualitative and quantitative analysis to investigate lexical features of Munro's works using AntConc software (3.4.4).

\subsection{Data Sources and Corpus:}

\subsubsection{The Main Corpus:}

The compiled corpus contains 13 collections including 143 short stories with the total number $(1,342,546)$ of word tokens, and $(28,146)$ word types. The corpus is all produced by Alice Munro beginning from "Dance of the Happy Shades" (1968) till "Dear Life" (2013). This study excludes Alice Munro's work "Lives of Girls and Women" as it is considered by the critics the only novel written by her. See appendix (1).

The collections under study are downloaded from www.amazon.com . They are downloaded as pdf files and then converted into Word documents so as to enable the researcher to go through the process of cleaning up the corpus and reach accurate results concerning number of words of the corpus under study. Afterwards, the texts are converted into plain texts so as to be appropriate for a computer software usage. Then the results are interpreted using AntConc 3.4.4 (2014) toolkits using the tools that provide the researcher with the top keywords for analysis, words frequency, collocations, and concordance lines that are of a great aid for the research to meet the research's objectives.

\subsubsection{Reference Corpus}

Thereferencecorpus is built up to be compared with the main corpus. This corpus is composed of various collections of male short story writers of other nationalities than Canadians writing in English. The reference corpus comprises $(2,292,075)$ word tokens, in addition to (44606) word types. The reference corpus is used as a background to the main corpus to show the characteristics of the main corpus. The reference corpus includes famous short story writers such as Leo Tolstoy, Roald Dahl,J.D Salinger, O' Henry, Jeffery Archer, William 
Somerst Maugham, Fyodor Dostoevsky, Ernest Hemingway, and Guy De Maupassant. See appendix (2)

\subsubsection{Corpus Refining:}

The corpus has gone through a state of cleaning by removing bibliography details in addition to dedications, tables of contents (including the names of the stories listed in the collection), introductions by Alice Munro or others, information about the publishers, notes about the author and acknowledgements are totally omitted. Similarly, at the end of some collections, the parts of "about the author", "others by Alice Munro" (including other collections produced by the same author), or the lines concerning the copyright are omitted. Afterwards, collections are converted into plain texts to be used through the computer software (AntConc 3.4.4)

\section{The analysis:}

This part is devoted to a full analysis of Alice Munro's use of the five most frequent lexis in order to see the stylistic features that characterize her writing. It first tracks the word frequency of the top most frequent words provided by the Word List tool showing the number of frequency and the rank in addition to their denotations and connotations using Oxford Dictionary. This is to investigate her lexical choices that reveal her linguistic attitude. Afterwards, the analysis explores the significance of the keyness value generated by the Keyword List tool and shows to what extent it is similar to or different from that used by male writers. This is to reach stylistic features characterizing Munro as a feminist writer and to what extent she is distinguished as a female. The analysis after that investigates the collocation patterns using the top words as "nodes". The analysis explores their collocates and their frequency using AntConc search result provided by the Collocates tool to test the collocations. The Collocates tool generates words that often appear in close association to the top five lexical items. The collocates that usually come before these top lexical items are analyzed for their thematic elements that characterize Munro's writing.

Table (1)

\begin{tabular}{|l|c|c|c|c|}
\hline & Rank & Keyword & Frequency & Keyness \\
\hline $\mathbf{1}$ & 65 & Time & 2880 & 49.139 \\
\hline $\mathbf{2}$ & 72 & Way & 2425 & 408.85 \\
\hline $\mathbf{3}$ & 74 & People & 2406 & 922.120 \\
\hline $\mathbf{4}$ & 86 & House & 1995 & 385.45 \\
\hline
\end{tabular}




\begin{tabular}{|l|l|l|l|l|}
\hline $\mathbf{5}$ & 119 & Home & 1365 & 350.8 \\
\hline
\end{tabular}

Table 1. Top most frequent lexical items

Table (1) provides the nouns recording the highest frequency to be analysed based on their connotative and denotative meanings to investigate the stylistic features that signal her as a feminist writer and representative of feminist writing. An exhaustive analysis of each lexical item is attempted in terms of denotations and connotations that are checked using Oxford Dictionary, their frequency, their rank, their keyness value, and their collocates.

\subsection{The lexical item "Time":}

\subsubsection{Quantitative Analysis:}

According to AntConc software, the most frequent item used by Munro within her corpus is the lexical item "time" with the frequency (2880) occupying rank (65). It records keyness value (49) approximately. This means that Munro uses this lexical item by keyness value (49) compared to the amount of using such an item within the reference corpus (male short story writers). Concerning the collocations, the most frequent adjectives that collocate the node "time" are "first" and "long" which measures the statistical strength (5.8). She uses "first time" (153) times and "long time" (146 times).

\subsubsection{Qualitative Analysis:}

According to Oxford Dictionary, the denotative meaning of the word "time" is "what is measured in minutes, hours, days, etc." The frequent use of this lexical item connotates that the writer is very accurate and conscious with precise details. This may yield the ideology and may reveal her as a person totally convinced by the importance of time and that her characters are precise and punctual.

Gilbert (1993) comments on Munro's interest in "time" throughout her narration. This is achieved not only through the straightforward lexical item "time" but also through the use of other temporal markers such as "last week", "next day" and others. Gilbert (1993) also comments, "Temporal markers are at times quite explicit" (1993, p.5)

In support of this, Julian Barnes and Lorrie Moore add that Munro is interested to move her characters through time in the process of narration. Barnes (2013) mentions that "Alice Munro can move characters through time in a way that no other writer can"(n.p). She also says that the reader is not aware that time 
is passing and she observes this in the sudden great change in the characters' lives. Barnes considers this ability of dealing with "time" is the reason that gives Munro's short stories great fame and density. She comments "I have sometimes tried to work out how she does it but never succeeded, and I am happy in this failure, because no one else can - or should be allowed to - write like great Alice Munro" (n.p). Moreover, Lorrie Moore (2013) comments on Munro's excessive use of time saying "If short stories are about life and novels are about the world, one can see Munro's capacious stories as being a little about both: fate and time" (n.p).

\section{For example:}

Concordance hit (25): Last year, just at this time, in March, the bulldozers had come in to clear away the brush and second growth and great trees of the mountain forest. (Dance of the Happy Shades)

In this example, Munro stresses the concept of time to link between the two incidents, cutting off the brush in terms of time as if it were a scheduled event. Gilbert (1993) stresses the fact that Munro is a writer obsessed with using time saying that "an essential characteristic of this feminist, postmodern, and postcolonial recreation of female self and maternal other is the construction of time and space"(p.7). This appears in her interests to attach the reader to the exact time and remind him by what happened last year to provide the reader with a space to think and link.

Concordance hit (15):All the time, I was preparing dinner and eating it, and talking to Gabriel and the children, I was thinking of a letter. (Dance of the Happy Shades)

Concordance hit (21) :All the time, one or the other is asking me about the baby-sitting. (Dance of the Happy Shades)

Sometimes, Munro uses "time" as an adverbial adjunct to reveal the idea of repetition. It implies persistence leaving a negative feeling on the character as she may get bored by this. According to her, whatever happens "all the time", as she refers, is the thing that is repeated more than once. She repeats "all the time" and gives impression that something is happening a lot. Gilbert (1993), in her comments on Munro's style, says "this text as exhibiting circular time, similar to 
the amorphous boundaries of a time-lapse camera... and a map of one's state of mind" (p.8)

Concordance hit (790): One time, one time, she wanted to give Daddy a scare. He was supposed to be interested in some girl that kept coming around to the works. (Progress of Love)

Munro's lexical repetition of "one time" is not only to refer to the exact time but she refers to the conceptual and spatial sense of time. Sometimes she uses "time" in the process of narration to capture the attention of the reader but not to refer to the known clock time.

Concerning the keyness value of the lexical item "time" by keyness value (49) which shows that female writers use the idea of time more than male ones. Felski (2002) supports this idea and proves that using time and referring to it in the process of narration is a significant characteristicof female writers. She adds "we all use time and make sense of time in quite different ways. In this dizzying proliferation times, woman is a faithful yet fluctuating presence" (n.p). At this point, it appears that this issue is only related to women rather than men. She completes her idea saying, "feminist scholars do not resolve this ambiguity but rather intensify it, telling many different stories about women and time". According to her, feminists use time, present it in different ways, and show it through various patterns. This is the reason why they are very frequent in Munro's collections. She comments on this saying, "all these patterns reach beyond the empty mechanical measure of clock time"(n.p). This also confirms the idea that time for female writers literally does not mean the clock time or the real time but is used sometimes by the writer to indicate generalization.

"Time" as a node is collocated with the adjectives "long" and "first" as the most frequent adjectives. This frequent association between "time" and these two adjectives may confirm the idea of accuracy adopted by the writer and the precise details provided through her narrative technique and reveals her as cautious about definite time. "Long time" refers to space of time, whereas "first time" refers to the sequence of time and shows the accuracy of the process of narration.

\section{For examples:}

Concordance hit( 7) : I have no idea it wasn't the first time, he said. If it was the first time, would a girl be smart enough to fill three bottles. (Dance of the Happy Shades) 
Concordance hit (9): That was what she said the first time and everybody in the front seats heard her. (Dance of the Happy Shades)

In these examples, Munro uses the collocation "first time" as an indication to determine the sequential occurrence of the events in terms of time and is a proof that the writer is interested in showing the characters in the frame of time.

Concordance hit (5): I have been divorced for a long time and so it is natural that Julie should talk to me about a problem. (Dance of the Happy Shades)

Concordance hit (6): She was taking a long time running the water, washing her hands, combing her hair (Dance of the Happy Shades)

The collocation "long time" here is used to refer to the duration and wide space of time. It supports the idea that the writer is interested in attaching everything in the characters' lives to time, either by referring to exact time of the incident or by giving a description to the status of her characters over a long period.

\subsection{The lexical item "way":}

\subsubsection{Quantitative Analysis:}

According to AntConc software, the second most frequent lexical item used by Munro is "way" with the frequency (2425) occupying the rank (72). The keyness value recorded by "way" that refers to the comparison between Munro's corpus and the reference corpus used through the keyword list of the AntConc software is (424) which may be considered among the highest ones. In other words, Munro refers to the way everything is done more than the use of male writers by keyness value (424).

At the level of collocations, the node "way" is accompanied by the collocates "same" and "other". In other words, she uses "same way" (45 times), "other way" (32 times). Moreover, investigating the pronouns that come with company of the lexical item "way", it is clear from the AntConc results that the writer uses "her way" (93times), and uses "his way" (69 times)

\subsubsection{Qualitative Analysis:}


According to Oxford Dictionary, the lexical item "way" may have multiple meanings according to the context, in addition to group of idioms that include "the same way'. In general, the denotative meaning of the word "way" is either "a method, style or manner of doing something" or "the typical way of behaving and living of a particular group of people". Besides, it has the meaning of "a route or road you can take to reach a place". At the connotative level, it gives the sense of extremely accurate details to the extent that whenever the writer discusses an issue or describes an event or character she identifies its way. This also confirms the idea of accuracy that distinguishes Munro's stylistic feature as a feminist. Awano (2006) comments on Munro's obsession to portray everything with details and says "she intricately dissects and charts whole lives, replete with enormous changes, with a thoroughness we might have thought only attainable in a novel." (n.p)

Actually, short stories are different from novels in the fact that novels are longer and full of details. Playle (2017)comments on the difference between novels and short stories saying that " a novel is a larger scale project that takes a lot more stamina than a short story" (n.p). This means that being a short story is an indication that the process of writing is totally free from details and the writer does not have to show the way everything is done. This indicates the second most frequent lexical item in Munro's corpus is "way" and the impression of too many details may be considered something strange.

On the other hand, unlike most of the short story writers, the critic May Charles (2012) comments on Munro's short stories in particular saying " The usual way that critics and reviewers try to account for the complexity of Alice Munro's stories is by calling it 'novelistic' “( (n.p). She confirms that Munro's short stories are full of details typically like a novel. The complexity and detailed incidents throughout the process of narration are the reason why the lexical item "way" is highly frequent.

In addition to this, through her review about Munro's narrative technique, Gilbert (1993) shows that the feminist Alice Munro is very interested to show the minute details in her characters and they present the same point from various and more than one point of view. This gives the reader the impression of repetition to visualize the idea. Gilbert (1993) comments "the greater number of critical analyses of the narrator in Munro's works not only provides a better understanding of her texts but also serves as a starting point of further study of the narrative position"'(p.4) 
Munro uses the lexical item "way" to indicate various meanings. Sometimes she uses "way" to refer to the road in its literal meaning. In other contexts, which are the majority, she uses "way" to express more details and to describe the way of every action

\section{For example:}

Concordance hit (11): On the way home, my father does not buy any ice cream or pop, but he does go into a country store and get a package of licorice, which he shares with us. (Dance of the Happy Shades)

In this example, she uses "way" in its literal meaning and refers to their way back to their home. Even when "way" is used in its literal meaning the writer resorts to another ways to provide too much details. She expresses what the father does not buy and not only what he buys.

Concordance hit (208): They turned onto Burns street heading for Clayton house, the nearest house belong to any of them. This was not the way home for Eva or for Carol either, but they followed along. (Something I've Been Meaning to Tell You)

In this example, "way" is used in its literal meaning that is a description of an address and indication of a real street. Although the literal meaning is the intention of the writer here but still she describes the way and the address to the character's home in details.

The majority of hits in which the writer uses the lexical item "way" her intention may be to show more details and present extra description. That is why the lexical item "way" is frequently preceded by adjectives.

\section{For example:}

Concordance hit (195): And you, you would smile in a certain way, in a gentle way; I think you were a good deal ashamed of me. (Something I've Been Meaning to Tell You)

Concordance hit (198): From the beginning, of course, I knew that this was a dangerous way to live. (Something I've Been Meaning to Tell You) 
Concordance hit (234): He was friendly enough, in what seemed a half-professional way, but she was cool. (Something I've Been Meaning to Tell You)

Concordance hit (245): Alert, intelligent, bony in a delicate way, often embarrassed. (Something I've Been Meaning to Tell You)

Through these examples, the writer uses the lexical item way preceded by adjectives to show the way everything happens to her characters. Sometimes, she shows the way everything happened but understood from the context and not by using adjectives.

\section{For example:}

Concordance hit (10): This is the way, now, this is how they dance. (Dance of the Happy Shades)

Munro here is referring to a certain group and within the process of narration and shows that they are dancing. From her point of view as a feminist concerned with too many details, she keeps describing the way they are dancing to the extent that makes the reader feels he is reading a novel with so many details and not a short story.

The keyness value (424) that is recorded by this word indicates that these novelistic features and the interest of the writer to show details is an exclusive feature for female writers and not males. In other words, when males are writing they are not concerned with showing the way anything is done.

\section{For example:}

Concordance hit (1451): I was stupid about these matters, in a way that was very risky, particularly for a woman of my age. (Hateship _ Friendship _ Courtship _ Loveship)

Munro here assumes that the speaker is stupid and describes that this stupidity is in a risky way and adds to her description that it is limited to females, and not only females but females of certain age. Her style of writing seems to be very precise and she never refers to something in general. She is always limiting and restricting her description to a certain character or a certain group of people. 
Concordance hit (1449): People who spoke English in a way unfamiliar to me if they spoke it at all. (Hateship _ Friendship _ Courtship_ Loveship)

Even when she speaks about a very general idea, which is "people who spoke English", she focuses on the way they do it by saying "unfamiliar". Indeed, it is very clear that people who speak English is a very huge number of people, and this assumed to be a very general idea, but through the style of Munro they are described and the way they speak is under investigation.

Regarding sense relations of lexical items, the lexical item "way" can be considered polysemy which means that it is a very wide lexis that has different meanings, as previously mentioned concerning its denotative meaning. Using a polysemy among the most frequent lexical items gives the impression that the writer generalizes the idea and intends to include females in general and not her characters only. Generally, it appears that she restricts and limits certain judgments on her characters and then generalizes it. Awana (2006) comments "Munro is not concerned with impressing the reader. The depth, beauty, and truth of the story she is writing are of greater concern to her" (n.p).

The node "way" is frequently accompanied by the collocates "same" and "other". In other words, she uses "same way" (45 times), "other way" (32 times). The two collocates seem to be contradictory to each others. In some contexts, she refers to something and what is similar to it in a "same way" and this is a technique used by Munro to generalize. In other contexts, she refers to something and what is different to it in "other way", and this how she limits certain actions and events to some of her characters only.

\section{For example:}

Concordance hit (1): Most of the people we knew are the same way, in the small town where we lived. (Dance of the Happy Shades)

The idea of generalization here is very apparent; she refers to the fact that all the people in her town have the same way.

Concordance hit (39): The teacher laughs in the same way she did before, and Jon gives her the direction about how to turn the car. (Too Much Happiness) 
The idea of generalization by using "the same way" here is not generalizing an action for all people but she generalizes the same attitude to one of her characters (the teacher)

The collocation "other way" is the second most frequent collocation that comes in company with the node "way", according to AntConc software.

\section{For example:}

Concordance hit (2): Sometimes I think about the way we lived out at home and the way we lived here and how one way was so hard to imagine when you were living the other way. (Something I've meaning to tell you)

Munro, through her character, differentiates between different ways of living and stresses on the way the character is living now using the collocation "other way". "Other way" is a kind of restricting the kind of life the character is living.

Concordance hit (14): When he spoke to her at rehearsals, there was never any suggestion that he ever spoke to her in any other way.(Dance of the Happy Shades)

"Other way" here is used to prove that the way this man is speaking is a very respectful way and excludes any other intention. It supports the idea that "other way" is to limit and restrict the behavior of Munro's characters and not to generalize.

\subsection{The lexical item "people":}

\subsubsection{Quantitative Analysis:}

The third most frequent lexical item used by Munro is "people" occupying rank (74) with frequency (2406). The keyness value provided by the Keyword List tool using AntConc software states that this lexical item records (922). The keyness value recorded by this lexical item is extremely high compared to other lexical items which means that Munro focuses on the different kinds of people more than male writers. Regarding collocates to the node "people", AntConc provides through it results that the most common adjectives come in company with "people" are as follows:

\section{Some people 143 times}




\begin{tabular}{|l|l|}
\hline Other people & 120 times \\
\hline Old people & 43 times \\
\hline Few people & 26 times \\
\hline
\end{tabular}

The first two highly frequent words that collocate the node "people" are not sufficient to show the kind of people Munro is focusing on and the various structures in which Munro uses "people". This is why the researcher extends the investigation to the second two collocates" old" and "few" to be able to test the kind of people Munro is following in her writing.

\subsubsection{Quantitative Analysis:}

At the denotative level, the lexical item "people" according to Oxford Dictionary (2004)has various meanings. First, it may mean "persons, men, women, and children". Second, people means "persons in general or everyone". Besides, it means "all the persons who live in a particular place or belong to a particular country". Furthermore, the lexical item "people" means "the ordinary men and women of a country rather than those who govern or have a special position in society". The multiplicity of definitions of the most frequent lexical items appears here vividly confirms the excessive use of polysemy and the writer's wide scope while presenting her issues.

Connotatively, the lexical item "people" gives the impression that the writer is discussing universal issues that can be applied to any group of people at any age. This justifies the fact that it is well known about Munro that she is presenting the people in her life through the characters of her short stories. Gilbert (1993) comments on this saying "Such complexities of narrative are not immediately evident in either text....Munro collection tells a good story about a narrator, her family and friends" (p.3). Similarly, Gilbert (1993) also comments on the nature of people in Munro's narration stating that "She seeks to write and edit the lives of people around her, along with her own, in a series of unsure recollections" (1993, p.5).

Munro is very interested to make the people in her real life visualized in her short stories because she feels they are symbolic kinds of people in our real life. This adds a feature to Munro's stylistic features which is the fact that Munro's readers will find themselves, and real people around them, depicted in the characters of Munro. Gilbert(1993) comments "she must leave her past and that of 
her mother, family and town in order to travel to a larger space of growth, only to return to her origins in Jubilee and transpose them into fiction".(p.8)

Similarly, Howells (1998) gives a comment about Munro's obssession of visualizing real people in her stories

certainly the fictions of Canada's greatest short story writer are tied to specific geographical locations, for Munro is fascinated by local history and geography and her story offers maps of small - town life in rural Ontario, though like women's gossip they also retail socially unspeakable events. (p.3)

In the same context, Awano (2006) comments on the nature of people included in Munro' stories

Alice Munro tells the large stories of people whose lives are outwardly small. Rarely does she write about the exceptional outsider. She is a great champion of ordinary outsiders, of people who in small and crucial ways don't fit, who need a better life than the one being offered to them (n.p)

Observing the concordance lines of the lexical item "people" in Munro's collections, the researcher finds that the majority of hits are used either preceded by adjectives or followed by relative pronouns "who" or "whose". The hits in which "people" is preceded by an adjective may be intended by the writer to regulate and constrain the reference of the word to certain kind of people, and this justifies the results of AntConc collocate tool that proves that the second two most frequent collocates that precede the node "people" are "old" and "few". Similarly, Munro uses the relative pronouns "who" and "whose" that frequently follow "people" to regulate and limit her comments to a certain kind of people and not the meaning of the word people in general.

\section{For example:}

Concordance hit (12): She did not talk to many old people any more. (Dance of the Happy Shades) 
Concordance hit (7):Very few people actually want that, or will admit they do, in a greedy and straightforward way. (Progress of Love)

In these examples, Munro is following her technique in which she limits her idea and description to a certain kind of people. That is why she offers adjectives before her most frequent lexical item "people". The adjectives "few" and "old" are among the top adjectives that precede the node "people". In the first example, Munro categorizes people according to their age and that her character "she" did not talk to specific old people. In the second example, the same technique of restricting certain people prevails. She refers to people who want to deal in a straightforward way as "few people".

\section{For example:}

Concordance hit (24): Living downstairs in the house were three young people. . (Something I've Been Meaning to Tell You)

Concordance hit (38): What a shock I got when I saw the kind of people there. Influential people. Wealthy people. Professional people. All cultured and educated top-drawer people. (Something I've Been Meaning to Tell You)

Concordance hit (54): My people are poor people. You would think the place I lived in was a dump. (Beggar Maid)

In these examples, Munro follows the same technique of narration in which she limits the kind of people she is talking about. She mentions "young", "influential", "wealthy", "cultured", "educated", "top", and "poor" people. Munro here appears to be a writer fascinated and obsessed with description due to the excess use of adjectives. It also shows that Munro, and other feminists, are convinced that people are of different categories and gives the impression that feminists are following the judgmental technique.

\section{For example:}


Concordance hit (13): She finds it natural and satisfying; people who believe in miracles do not make such fuss when they actually encounter one. (Dance of the Happy Shades)

Concordance hit (41): Her sense of order and modulation elsewhere exposed such embarrassing sad poverty, in people who never thought themselves poor. (Beggar Maid)

Concordance hit (11): It is already fairly full of people whose journey home starts in this town. (View from Castle Rock)

In these examples, Munro is sticking to the same style when describing people. She frequently describes the people and categorizes them. For instance, in the first example, she refers to people specially those who believe in miracles. Similarly, in the second example, she restricts her reference to people who are poor but never consider themselves poor. In the third one, she refers to people who start their life journey from her town. Finally, she refers to people who are transferred from their hometown to live elsewhere.

Bearing in mind that Munro traveled from her town Ontario in Canada and lives in another country when she grows up, one can observe that most of the people mentioned through Munro's stories are real characters in her life and are typically imitated in her fiction.

On the other hand, the lexical item "people" in Munro's is works not limited to certain people under various categories portrayed by Munro, but sometimes she refers to people in general. Actually, the concordance hits referring to people in general are rare but still exist.

\section{For example:}

Concordance hit (300): During the depression, people could not afford to pay more, perhaps, but he continued the practice through the war, through the years of the prosperity after the war, until he died. (Beggar Maid) 
Concordance hit (730):People wanted to talk face to face. They had to get out and do it, inspite of the cold. (Progress of Love)

The lexical item "people" here is very general. She first mentions people during depression in general and their feeling during the war. In the second example, Munro gives a comment about all people that they want to talk to each other face to face without categorizing which means this is a common desire for all people.

\subsection{The lexical items "house" and "home":}

\subsubsection{Quantitative Analysis:}

Munro uses the lexical item "house" at rank (86) with the frequency (1995).The keyness value provided by the Keyword List tool using AntConc software states that this lexical item records (401). The keyness value recorded by this lexical item is extremely high compared to other lexical items. This means that Munro refers to houses or the place where people live in frequently through her stories more than male writers do. On the collocation level, "old" (19 times) and "big" (14 times) are the highest adjectives that often precede the lexical item "house". Investigating the most frequent pronouns that most probably come with the noun "house", it appears, through AntConc software that Munro mentions "his house" (63 times), and "her house" (48 times).

The lexical item "house" may be considered a near synonym with the lexical item "home" with some connotative differences. "Home" also appears in the results of AntConc software at rank (119) which is considered a high rank. It is not to be counted among the top hundred but it is very important to discuss the reasons why Munro resorts to "house" more than "home" and to investigate the reasons and the contexts in which each one of them is frequent. This is to reach a vivid picture about the lexical choices Munro focuses on and then reach some of her stylistic and lexical characteristics that contribute to her feministic views

The keyness value provided by the Keyword List tool using AntConc software is (350). The keyness value of "home" recorded by this lexical item is among the highest values scored by lexical items but is lower than that of the "house". This means that Munro refers to the home and the comfort her characters feel at home more than male writers do but it is not more than "house" in Munro's corpus. 


\subsubsection{Qualitative Analysis:}

The denotative meaning of the frequent lexical item "house", according to Oxford Dictionary, is "a building for people to live in". Based on the idea of sense relations, the word "house" is sometimes considered a synonym or near synonym of the lexical item "home", but "home" (which is not used by Munro) carries extra connotations. "House" refers only to the place where people live, while "home" refers more to the idea of emotional stability and warm feeling and sense of stability, excess of feelings besides the place of living. Mallett (2004) in her research about understanding home in literature, comments on the meaning of "home" stating that in it "I feel comfortable and secure. I am at home. Sleep comes quickly" (p.62). Moreover, she comments, "In my account, home is a virtual place, repository for memories of the lived spaces. It locates lived time and space, particularly intimate familial time and space" (p.65)

The excess use of "home" more than "house" in Munro's works may mean the place where people live and enjoy spiritual comfort. Conversely, Munro sticks to the lexical item with more sharp connotations apart from any feelings and emotions; she means the place of living in its literal meaning. This may perhaps imply that she is only keen to express her ideas concerning female status in the society apart from any feelings and emotions for her characters. Furthermore, Awano (2006) comments "Alice stories are so place- and time specific". This may reveal that she means only the place without any emotions.

Mallette refers to Saunders and Williams when they say

Precisely because the home touches so centrally on our personal lives, any attempt to develop a dispassionate social scientific analysis inevitably stimulates emotional and deeply fierce argument and disagreement. The home is a major political background - for feminists, who see it in the crucible of gender domination (p.91).

Literally, "home" is not "house" and they never conflate with each others. Mallett (2004) comments that ' the meaning of home neither conflates home with house or family''(n.p).

"House" is always referred to by Alice Munro when she means to refer to a place where people normally live, interact, cook, eat, drink, and practice natural 
life , apart from any warmth and mutual feelings among people who are living. It is just a place where actions take place and nothing more.

\section{For example:}

Concordance hit (25): All the meals in that house, the cooking, the visiting, the conversation, even someone playing on the piano; all this life going on (Dance of the Happy Shades)

The character who says this sentence uses "house" as a place in which concrete actions such as cooking, visiting, and playing piano take place.

Concordance hit (42): I knew she meant what had happened in the house, and I laughed too, not knowing what else to do. (Dance of the Happy Shades)

The reference to the "house" here is just a place in which the action happens takes place. It is only the theatre of the scene apart from any intentions , emotions and feelings.

Concordance hit (360): Our house was descent too; an old brick house of a fair size, but it was drafty and laid out in an inconvenient way. (Beggar maid)

The house mentioned here is described in detail concerning the kind of the bricks used in its building, its size, and the way it is laidout.

On the collocation level, the most frequent adjectives preceding "house" are "big" and "old"

\section{For example:}

Concordance hit (14): You have never seen the inside of my new, I mean newly decorated and new to me house. Or even my old house, now that I come to think of it. (Runaway)

Concordance hit (13): Actually, now that the big house was gone, a good deal of her was gone with it. (Dear Life) 
On the other hand, Munro uses the lexical item "home" when she refers to any action referring to her memory of feeling or conscious. In this context, Mallett (2004) comments "home brings together memory and longing, the ideational, the affective and the physical, the spatial and the temporal, the local and the global, the positively evaluated and the negatively" (p.10). Moreover, Mallett (2004) refers to the idea of "home" in literature "Home is often described in the literature as a heaven or refuge. It is depicted as a place and/or space where people can retreat and relax" (p.12)

\section{For example:}

Concordance hit (6): She hasn't been home for five years. I guess she finds something better to do with her holidays. (Dance of the Happy Shades)

The lexical item "home" here is not the place in which she lives, but it refers to her country and her sense of belonging and her feeling towards her country.

Concordance hit (82): I have been to visit Aunt Annie and Auntie Lou. This is the third time I have been there since I came home and each time they have been spending the afternoon making rugs out of dyed rugs. (Dance of the Happy Shades)

The speaker here means that she wants to visit her aunts and to enjoy the warmth with her relatives, and adds that this is the first time she will visit them since she returned back to her country (home).

Concordance hit (83): Certainly I never saw them argue in all the years when Maddy and I used to visit them, and we used to visit them often not only out of duty but because we found the atmosphere of sense and bustle reassuring after the comparative anarchy, the threatened melodrama, of our house at home. (Dance of the Happy Shades)

The actions in the context of the "home" here are a clear indication that "home" is used to express feelings and emotions apart from concrete actions and daily routine. The writer refers to certain verbs such "argue" and "reassure". Moreover, the speaker refers to the atmosphere and to her feelings in her visit to her friends. 


\section{Conclusion:}

To sum up, this research has investigated the nature of the most frequent lexical items chosen by Munro and to what extent they indicate her beliefs and ideology and show her stylistic features. This is achieved through focusing on the frequency of the top five lexical items along with their ranks, collocations, and keyness values and the indication of this. The lexical features investigated through the study are:

1- Munro's frequent use of the lexical item "time" in its various meanings in addition to other temporal markers indicates her accuracy and precise attitude. Besides, it confirms that she is a writer who is interested in including the element of time through the process of narration.

2- The high frequency and high keyness value of the lexical item "way" proves Munro to be a writer totally obsessed with details more than male writers.

3- Using the lexical item "people" in a very frequent way proves Munro to be universal in her approach and confirms the fact that her characters are representatives of real people and true characters in life.

4- Munro uses "home" and "house" among the most frequent items in which "house" is more frequent. Discussing the denotations and connotations of both proves Munro to be somehow far from showing her characters' feelings and emotions. Besides, she prefers to choose lexical items with sharp and concrete connotations.

\section{References}

\section{Primary Sources:}

Munro, A. ( 1990.). Freind of My Youth. New York : Alfred A. Knopf,a division of Random House, Inc.,.

Munro, A. (1968). Dance of the Happy Shades. Canada: The Ryerson Press.

Munro, A. (1974). Something I've Been Meaning to Tell You. New York: McGraw-Hill Ryerson Limited.

Munro, A. (1978). The Beggar Maid. Canada: The Macmillan Company of Canada Limited .

Munro, A. (1982). Moons of Jupitar. Canada: The Macmillan Company of Canada Limited

Munro, A. (1986.). Progress of Love. New York: Alfred A. Knopf, a division of Random House, Inc.

Munro, A. (1990). Open Secrets. New York: Vintage Books. 
Munro, A. (1996). Love of a Good Woman. Canada: McClelland \& Stewart Inc. The Canadian Publishers.

Munro, A. (2001). Hateship, Freindship, Loveship, Courtship, Marriage. Canada: McClelland \& Stewart Ltd. The Canadian Publishers.

Munro, A. (2004). Runaway. Canada: McClelland \& Stewart Ltd. The Canadian Publishers.

Munro, A. (2006). A View From Castle Rock. New York.: Alfred A. Knopf, a division of Random House, Inc.,.

Munro, A. (2009). Too Much Happiness. Canada: McClelland \& Stewart, Toronto.

Munro, A. (2012). Dear Life .New York.: Alfred A. Knopf,a division of Random House, Inc.,.

\section{Secondary Sources:}

Awano, L. D. (Summer 2006). Appreciations of Alice Munro. The Virginia Quarterly Review, 82(3), 91. Retrieved from www.Questia.com

Baldick, C. (2001). The Concise Oxford Dictionary of Literary Terms. New York: Oxford University Press.

Barnes, J. (2013, October 10). Writers on Munro. Retrieved from The New Yorker: https://www.newyorker.com/books/page-turner/writers-on-munro

Biber, D. (2011). Corpus Linguistics and the Study of Literature. Back to Future? Scientific Study of Literature, 15-23.

Bosman, J. (2013, October 10). Alice Munro wins Noble Prize in Literature. Retrieved from The New York Times: https://www.nytimes.com/2013/10/11/books/alice-munro-wins-nobel-prize-inliterature.html

Bright, W. (1992). International Encyclopedia of Linguistics. New York Oxford: Oxford University Press.

Charles, M. (2012). The Short Story's Way of Meaning: Alice Munro’s “Passion”. Narrative, 20(2). Retrieved from https://muse.jhu.edu/article/476756

Cruse, D. A. (2004). Meaning in Language: An Introduction to Semantics and Pragmatics. . Oxford University Press.

Crystal, D. (1997). The Cambridge Encyclopedia of Language. Cambridge University: Cambridge University press.

Culpeper, J. (2009). Keyness: Words, parts of speech and semantic categories in the character-talk of Shakespeare's Romeo and Juliet. International Journal of Corpus Linguistics, 14, 29-59. 
Duncan, I. (2011). Alice Munro's Narrative Technique. New York: Palgrave Macmillan.

Ezzat, A. G. (1973). Aspects of Language Study. Beirut: Bouheiry Brothers.

Felski, R. (Spring, 2002). Telling Time in Feminist Theory. Tulsa Studies in Women's Literature, 21(1), 21-28 . Retrieved from http://www.jstor.org/stable/4149213

Fischer-Starcke, B. (2009). Keywords and Frequent Phrases of Jane Austen's Pride and Prejudice: A Corpus Stylistic Analysis. International Journal of Corpus Linguistics, 14, 492-523.

Flowerdew, L. (2012). Corpora and Language Education. China: PALGRAVE MACMILLAN.

Gilbert, P. R. (1993, June). All Roads Pass rpigh Jubilee : Babrielle Roy's La Route d'Altamont and Alice Munro's Lives of Girls and Women. Cobly Quarterly, 29(2), pp. 136-148. Retrieved from https://digitalcommons.colby.edu/cgi/viewcontent.cgi? article=2963\&context=cq

Halliday, M.A.K (1996). Lexis as Linguistic Level. In Bazell, C.E. \&. Firth, J.R (Eds.), In Memory of J.R. Firth (pp.148-162). London: Longman

Hamp, E. P. (1966). A Glossary of American Technical Linguistic Usage 1925-1950. University of Chicago: Spectrum.

Hoey, M. (1998). Some text properties of certain nouns. In T. McEnery and S. Botley, Proceedings of the Colloquium on Discourse Anaphora and Reference Resolution. Lancaster: University of Lancaster.

Hoey, M. (2005). Lexical Priming: A New Th eory of Words and Language. London: Routledge.

Hooper, B. (2008). The Fiction Of Alice Munro : An Appreciaition. United States of America: Praeger. Retrieved from https://books.google.com.eg/books?hl=en\&lr=\&id=AXlm0NurSGYC\&oi=fnd\&pg=PR5\&dq=t he+fiction+of+Alice+Munro:an+appreciation\&ots=IXydefrDi4\&sig=U6EDbISofLju 7xvaCfTPleyoV8\&redir_esc=y\#v=onepage $\& q=$ the $\% 20$ fiction $\% 20$ of $\% 20$ Alice $\% 20$ Munro $\%$ 3 Aan $\% 20$ appreciation $\& \mathrm{f}=$ false

Howells, C. A. (1998). Alice Munro Contemporary World Writers. Canada: Manchester University Press.

Hunston, S. (2002). Corpora in Applied Linguistics. Cambridge University Press.

Jackendoff, R. (1983). Semantics and Cognition. London, England: The MIT Press Cambridge Massachusetts.

Kennedy, G. (1998). An Introduction to Corpus Linguistics. London: Longman.

Leech, G. (1990). Semantics: The Study of Meaning (2nd edition ed.). Penguin Books. 
Mallett, S. (2004, February 27). Understanding home: a critical review of the literature. The Sociological Review, 52(1), 62-89. Retrieved from https://onlinelibrary.wiley.com/doi/full/10.1111/j.1467-954X.2004.00442.x

Matthews, P. (2005). The Concise Oxford Dictionary of Linguistics. Canada: Oxford University press.

Moore, L. (2013, October 10). Writers on Munro. Retrieved from The New Yorker: https://www.newyorker.com/books/page-turner/writers-on-munro

Myszor, F. (2001). The Modern Short Story. Cambridge UP.

Partington, A. (1998). Patterns and Meanings. Amsterdam: John Bemjamins.

Playle, S. (2017). The Difference Between Short Story and Novel Writing. Retrieved from Liminal Pages.

Redekop, M. (1992). Mothers and Other Clowns: The Stories of Alice Munro. New York: Routledge. Retrieved from https://books.google.com.eg/books?id=b74TAwAAQBAJ\&printsec=frontcover\&dq=Mothers+and+othe $\underline{\mathrm{r}+\text { clowns }+(\text { Routledge+Revivals }):+ \text { The }+ \text { stories }+ \text { of }+ \text { Alice }+ \text { Munro \&hl=en \&sa }=X \& v e d=0 \text { ahUKEwiAmI6 }}$ g0YvaAhVOalAKHU3YCPMQ6AEIJTAA\#v=onepage\&q=Mothers\%20and\%20other\%20clowns\%20( Routl

Sally Wehmeier, M. A. (Ed.). (2004). Oxford Advances Learner's Dictionary of Current English (sixth edition ed.). New York: Oxford University Press.

Silverstein, L. B. (1996, March). FATHERING IS A FEMINIST ISSUE. Psychology of Women Quarterly, 20(1), 3-37.

Sinclair, J.M. (1966). Beginning the Study of Lexis. In Bazell, C.E. \&. Firth, J.R (Eds.), In Memory of J.R. Firth (pp.410-430). London: Longman

Sinclair, J.M. (1991). Corpus, Concordance, Collocation. Oxford: Oxford University Press.

Storey, T. (2017). A Noble Vision: The works of Alice Munro. Retrieved from https://theculturetrip.com/north-america/canada/articles/a-nobel-vision-the-works-of-alicemunro/

Stubbs, M. (1996). Text and Corpus Linguistics. London : Blackwell.

Stubbs, M. (2001). Words and Phrases: Corpus Studies of Lexical Semantics . Oxford: Blackwell.

W.R.Martin. (1987). Alice Munro Paradox and Parallel. Canada: The University of Alberta Press. 


\begin{tabular}{|r|c|c|c|}
\hline & Name of the collection & $\begin{array}{c}\text { Number of } \\
\text { short stories }\end{array}$ & Number of words \\
\hline 1 & Dance of the Happy Shades (1968) & 15 & 83,426 \\
\hline 2 & $\begin{array}{c}\text { Something I've Been Meaning to Tell You } \\
\text { (1974) }\end{array}$ & 13 & 87,301 \\
\hline 3 & $\begin{array}{c}\text { Who Do You think You Are? (1978)(also } \\
\text { published as The Beggar Maid) }\end{array}$ & 10 & 86,965 \\
\hline 4 & The Moons of Jupiter (1982) & 12 & 94,520 \\
\hline 5 & The Progress of Love (1986) & 11 & 122,416 \\
\hline 6 & Friend of my Youth (1990) & 10 & 102,673 \\
\hline 7 & Open Secrets (1994) & 7 & 100,740 \\
\hline 8 & The Love of a Good Woman (1998) & 8 & 120,482 \\
\hline
\end{tabular}




\begin{tabular}{|r|c|c|c|}
\hline 9 & $\begin{array}{c}\text { Hateship, Friendship, Courtship, Loveship, } \\
\text { and Marriage (2001) }\end{array}$ & 9 & 117,159 \\
\hline 10 & Runaway (2004) & 13 & 113,426 \\
\hline 11 & (2006)The View from Castle Rock & 11 & 111,162 \\
\hline 12 & Too Much Happiness (2009) & 10 & 106,093 \\
\hline 13 & Dear Life (2012) & 14 & 96,183 \\
\hline & TOTAL & $\mathbf{1 4 3}$ & $\mathbf{1 , 3 4 2 , 5 4 6}$ words \\
\hline
\end{tabular}

Table (2): Main Corpus 
Appendix (2)

\begin{tabular}{|c|c|c|c|c|}
\hline & Name of the collection & $\begin{array}{r}\text { Written } \\
\text { by }\end{array}$ & $\begin{array}{r}\text { Number } \\
\text { of short } \\
\text { stories }\end{array}$ & $\begin{array}{lr}\text { Number } & \text { of } \\
\text { words }\end{array}$ \\
\hline 1 & Eleven Stories by Tolstoy & $\begin{array}{r}\text { Leo } \\
\text { Tolstoy }\end{array}$ & 11 stories & 28,107 words \\
\hline 2 & $\begin{array}{cc}\text { 2The collected Short } & \begin{array}{l}\text { Stories of } \\
\text { Roald Dahl }\end{array} \\
\text { (Volume I) }\end{array}$ & $\begin{array}{r}\text { Roald } \\
\text { Dahl }\end{array}$ & 25 stories & 180,923 words \\
\hline 3 & $\begin{array}{r}\text { The Collected Short Stories of Roald } \\
\text { Dahl (Volume II) }\end{array}$ & $\begin{array}{r}\text { Roald } \\
\text { Dahl }\end{array}$ & 19 stories & 133,423 words \\
\hline 4 & Nine Short Stories by J.D Salinger & $\begin{array}{r}\text { J.D } \\
\text { Salinger }\end{array}$ & 9 stories & 54,911 words \\
\hline 5 & $\begin{array}{r}\text { Short Stories of } 100 \text { Selected Short } \\
\text { Stories, by O'Henry }\end{array}$ & O' Henry & 15 stories & 42,441 words \\
\hline 6 & $\begin{array}{c}\text { The Collected Short Stories of } \\
\text { Jeffrey Archer }\end{array}$ & $\begin{array}{l}\text { Jeffery } \\
\text { Archer }\end{array}$ & 38 stories & 229,256 words \\
\hline 7 & Sixty - Five Short Stories & $\begin{array}{r}\text { William } \\
\text { Somerst } \\
\text { Maugham }\end{array}$ & 65 stories & 551,609 words \\
\hline 8 & White Nights and Other Stories & $\begin{array}{r}\text { Fyodor } \\
\text { Dostoevsk } \\
\mathrm{y}\end{array}$ & 7 stories & 121,703 words \\
\hline 9 & $\begin{array}{r}\text { The complete Short Stories of Ernest } \\
\text { Hemingway }\end{array}$ & $\begin{array}{r}\text { Ernest } \\
\text { Hemingwa } \\
\mathrm{y}\end{array}$ & 60 stories & 267,289 words \\
\hline 10 & $\begin{array}{r}\text { Complete Short Stories of Guy De } \\
\text { Maupassant }\end{array}$ & $\begin{array}{rr}\text { Guy } & \text { De } \\
\text { Maupassa } & \text { nt } \\
\end{array}$ & $\begin{array}{r}10 \\
\text { volumes }\end{array}$ & 548,905 words \\
\hline & TOTAL & \multicolumn{3}{|c|}{ 2,292,075 words } \\
\hline
\end{tabular}

Table (3): Reference Corpus 